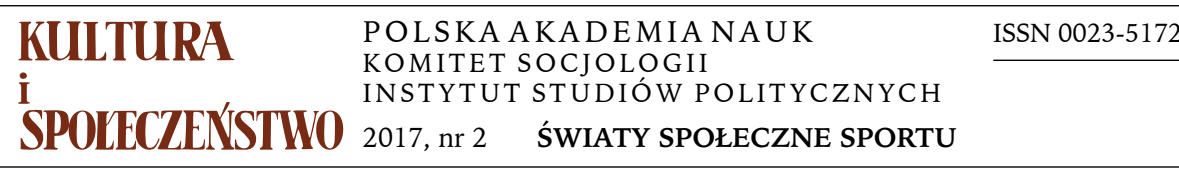

JOWITA WYCISK

MONIKA ZIELONA-JENEK

Uniwersytet im. Adama Mickiewicza $w$ Poznaniu

\title{
KONSTRUKCJA STEREOTYPOWEGO WIZERUNKU MĘŻCZYZN I KOBIET W WYBRANYCH POLSKICH PUBLIKACJACH NAUKOWYCH Z DZIEDZINY PSYCHOLOGII
}

W jaki sposób współczesne polskie publikacje naukowe mieszczące się $\mathrm{w}$ obszarze psychologii wpisują się w kulturową konstrukcję płci, rozumianej jako kategoria społeczna? Takie sformułowanie pytania oparte jest na ideach konstrukcjonizmu społecznego i określonym sposobie rozumienia kategorii „płeć”, co poddajemy analizie na wstępie. Uznając wielorakie znaczenie kategorii płci dla funkcjonowania zarówno pojedynczego człowieka, jak i grup społecznych, nie podejmujemy w tym miejscu analizy jej istoty (czym płeć jest i skąd się bierze). Postawione pytanie dotyczy sposobu używania tej kategorii w publikacjach naukowych, a zatem skłania do uważnego pochylenia się nad metodologią badań prowadzonych na gruncie psychologii, formułowanymi na ich podstawie wnioskami oraz społecznymi konsekwencjami ich upowszechniania $\mathrm{w}$ określonej formie. Opierając się na tezie, zgodnie z którą nauka jako istotna dziedzina kultury (Kamiński 1992) — w znacznej mierze oddziałuje na rzeczywistość społeczną, uznajemy znaczenie dbałości o jak najwyższe standardy jej uprawiania i rozpowszechniania, a przedstawione rozważania stanowią - w naszym zamyśle — głos na rzecz tej sprawy.

\section{PODSTAWY TEORETYCZNE}

Jak powstaje wiedza naukowa - podstawowe założenia konstrukcjonizmu

Analiza sposobów powstawania wiedzy naukowej (a zatem także wiedzy psychologicznej) stanowi przedmiot zainteresowań filozofii i socjologii nauki.

Adres do korespondencji: jowita@amu.edu.pl; monikazj@amu.edu.pl 
Dotyczą one między innymi zagadnień epistemologicznych określających istotę procesu poznawania świata oraz natury związków między tym co poznawane a procesem poznania.

Choć myśl konstrukcjonistyczna ${ }^{1}$ nie tworzy spójnej i jednolitej orientacji teoretycznej, cechę wspólną zróżnicowanych jej nurtów stanowi negacja założenia, iż wiedza jest (czy też może być / powinna być) mniej lub bardziej trafną reprezentacją obiektywnie istniejącego świata. To człowiek jest podmiotem aktywnie wytwarzającym / konstruującym wiedzę lub - w ujęciu radykalnym - aktywnie wytwarzającym ów świat. Trzeba w tym miejscu dodać, że konstrukcjoniści koncentrują się na rozważaniach dotyczących rzeczywistości kulturowo-społecznej, nie zaś - rzeczywistości fizykalnej (Wendland 2011). Zakłada się, że w miejsce biernego obserwowania i odzwierciedlania rzeczywistości w akcie poznania człowiek aktywnie konstruuje znaczenia, które zwrotnie kształtują i organizują jego percepcję i interpretację doświadczenia. W to aktywne konstruowanie wiedzy zaangażowane są więc $z$ jednej strony procesy poznawcze zachodzące $\mathrm{w}$ umyśle podmiotu, $\mathrm{z}$ drugiej zaś - procesy społeczne i kulturotwórcze, w tym zwłaszcza językowe formy komunikowania się (por. Wendland 2011; Zwierżdżyński 2012).

Nie chcąc wnikać w zróżnicowane założenia poszczególnych postaci konstrukcjonizmu, przedstawiamy tu kluczowe tezy tej jego odmiany, która posłuży nam jako ogólna teoretyczna rama zaprezentowanych analiz. Konstrukcjonizm społeczny (bo o nim tu mowa) znajduje zastosowanie właśnie w odniesieniu do zagadnienia konstruowania pojęcia płci, które poddamy oglądowi (Beall 2002). Oto najważniejsze założenia konstrukcjonistyczne sformułowane przez Kennetha Gergena (1985):

1. Krytyczny stosunek do pojęć uznawanych za obiektywną podstawę wiedzy. Konstrukcjoniści zachęcają do zawieszenia i/lub podania w wątpliwość założeń akceptowanych jako oczywiste.

2. Uznanie wiedzy o świecie za „społeczny artefakt”. Określony sposób rozumienia świata jest efektem aktywnego współdziałania ludzi pozostających $\mathrm{w}$ relacjach, zależnym od kontekstu historyczno-kulturowego, w jakim zostaje przez nich wytworzony.

3. Wskazanie, iż trwałość i powszechność danej wizji rzeczywistości zależy od zmiennych procesów społecznych, mechanizmów kontroli, osobistych upodobań, subtelnych procesów komunikacji, negocjacji czy retoryki.

4. Uwypuklenie związku między wiedzą a praktyką społeczną. Określona wizja rzeczywistości podzielana przez wspólnotę oddziałuje na życie jednostek

\footnotetext{
${ }^{1} \mathrm{~W}$ polskiej literaturze przedmiotu próżno by szukać konsekwencji w stosowaniu pojęć „konstrukcjonizm” i „konstruktywizm”. Zgodnie z sugestią Marcina Zwierżdżyńskiego (2012), pojęcie konstrukcjonizmu stosujemy jako nadrzędne i bardziej ogólne w stosunku do konstruktywizmu i konstrukcjonizmu społecznego, jakkolwiek zdajemy sobie sprawę z istnienia stanowisk odmiennych (por. Wendland 2011).
} 
poprzez tworzenie struktur społecznych i kształtowanie przebiegu interakcji międzyludzkich.

Konstrukcjonizm społeczny, jako orientacja metodologiczna, podejmuje dyskusję z tradycją pozytywistyczną w nauce. Kwestionuje możliwość dokonywania opisu rzeczywistości przez niezaangażowanego obserwatora, wskazuje także na rolę osobistych postaw i wartości w uznawaniu określonych informacji za fakty naukowe (Gergen 1985; Howard 1985). Jednocześnie zachęca do krytycznej analizy procesu wytwarzania wiedzy, obejmującej warunki, w jakich proces ten przebiega oraz jego społeczne, polityczne i ekonomiczne konsekwencje (West, Fensermaker 2003) ${ }^{2}$.

Analiza ta pozwala także na podniesienie kwestii etycznych w nauce, na przykład postawienie pytania o wartości wbudowane w określony sposób wyjaśniania zjawisk (Gergen, Davis, 1997). Uznając, iż każdy opis rzeczywistości uzależniony jest od kulturowych i historycznych warunków, a ludzie żyjący w obrębie danej społeczności różnią się między sobą sposobem postrzegania świata, konstrukcjoniści postulują konieczność współpracy jednostek na rzecz wytworzenia warunków wspólnoty, kompromisu i szacunku dla światopoglądowego zróżnicowania.

Publikacja naukowa jako szczególny etap konstruowania wiedzy naukowej przez badacza

Publikacje naukowe posłużą nam tu jako teksty kulturowe dostarczające przykładów konstruowania kategorii płci w psychologii. W przebiegu poznania naukowego interesujący wydaje się zarówno proces powstawania publikacji naukowej, jak i jej dalsze losy, w tym oddziaływanie na środowisko specjalistów $z$ danej dziedziny i laików. Ludwik Fleck (1986) zwraca uwagę, iż poznanie naukowe jest procesem zbierania wyników badań i budowania poglądów osób zanurzonych w tzw. styl myślowy własnej grupy odniesienia ${ }^{3}$. Chodzi przy tym zarówno o styl myślowy uprawiania nauki wytworzony przez społeczność naukową, „fachowców”, jak i o styl odzwierciedlający potoczny obraz "faktów naukowych" obecny w szerszym otoczeniu badacza. Efekty pracy naukowca, upowszechniane między innymi w postaci publikacji, należy zatem określić jako owoc szerszych oddziaływań niźli tylko jego fachowej wiedzy (zob. rys. 1).

Publikując tekst naukowy, autor ogłasza tezy będące efektem indywidualnej pracy, a także odzwierciedlające wiedzę i poglądy środowiska społecznego,

\footnotetext{
${ }^{2}$ Warto podkreślić, że znaczenie społecznych i historycznych uwarunkowań uprawiania nauki oraz kształtowania poglądów naukowych jest podnoszone także przez autorów reprezentujących orientację pozytywistyczną (zob. Bilikiewicz 1986; Brzeziński 2004).

3 Fleck (2006, s. 160) w szczególnym znaczeniu używał pojęć „fakt naukowy” (we wcześniejszych pracach) i „pogląd naukowy” (w późniejszych). Podkreślał tymczasowość i kontekstualne osadzenie tego, co uznawane jest w nauce w danym momencie za odkryte, udowodnione: „Fakt zawsze jest pewnym wydarzeniem związków historyczno-myślowych".
} 
Rysunek 1

Publikacja naukowa jako wytwór badacza i jego kontekstu społeczno-kulturowego

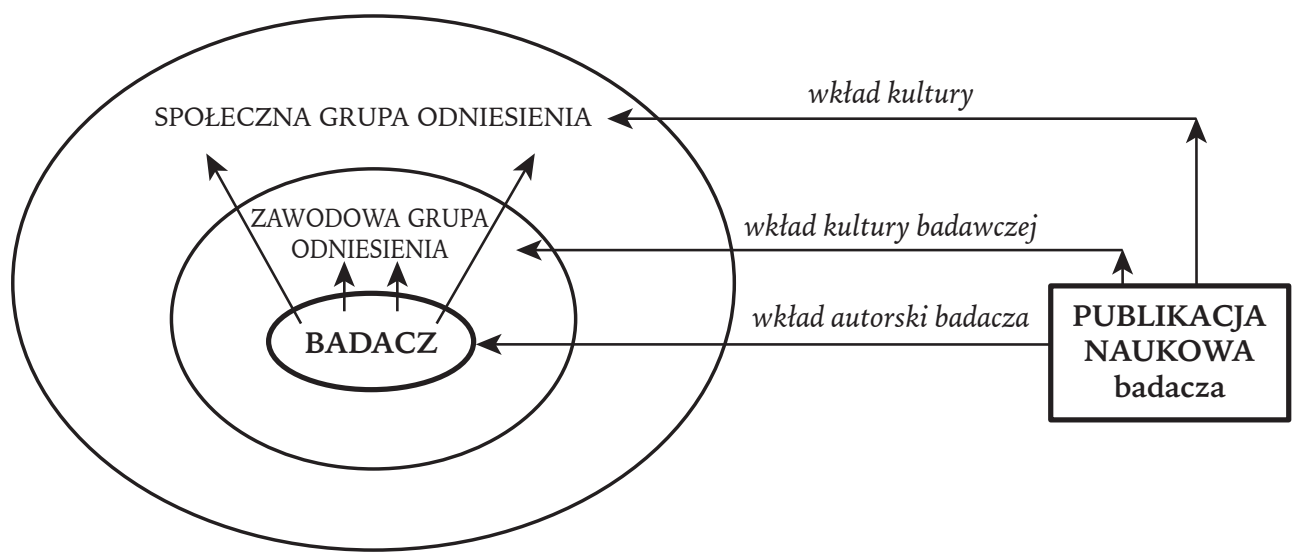

z którego się wywodzi. Wpływy otoczenia naukowca to: po pierwsze, wkład kultury badawczej jego grupy zawodowej oraz, po drugie, oddziaływania szerszej kultury jego społecznej grupy odniesienia. Do pierwszej kategorii należą idee i myśli będące przedmiotem wymian między współpracownikami. Ich znaczenie znajduje odzwierciedlenie $\mathrm{w}$ rozpoznawalnych w gronie naukowców tradycjach i szkołach. Kultura badawcza obejmuje także uznany przez grupę sposób gromadzenia i przetwarzania danych (zob. Pankalla 2013) i ogłaszania efektów pracy w postaci publikacji. Te ostatnie pozostają silnie związane $z$ instytucjonalnym kontekstem pracy naukowej, kryteriami oceny wartości dorobku badaczy, warunkami awansu zawodowego i określonymi przez nie przywilejami, jak również organizacją i finansowaniem badań czy wydawnictw.

Druga kategoria oddziaływań, którym podlega praca badacza, obejmuje kulturowe symbole i znaczenia, normy regulujące stosunki między ludźmi (prawne, obyczajowe), działania instytucji czy sprawowanie władzy (ich znaczenie dla nauki widoczne jest na przykład w zależnym od kontekstu historyczno-politycznego zakresie międzynarodowej współpracy badawczej). To tu mieszczą się także oddziaływania światopoglądów oraz uważanych za oczywiste przekonań wiedzy potocznej. Oddziałują one na naukowca zarówno w toku jego wczesnego rozwoju i edukacji (gdy nabywa wiedzę o świecie w uproszczonej formie), jak i w trakcie poszukiwania odniesień i inspiracji w życiu codziennym. Tworzą też ogólne ramy dla osadzania zagadnień szczegółowych podejmowanych na niwie poznania naukowego.

Specyfika poznania w nakach społecznych

Opisane zagadnienia dotyczące wzajemnych związków wiedzy naukowej i potocznej nabierają szczególnego znaczenia w naukach społecznych, w tym 
także w psychologii. Specyfiką nauk społecznych jest to, że poznający i poznawany, badacz i obiekt badany są tacy sami: posługują się tymi samymi zdolnościami pobierania i przetwarzania informacji $\mathrm{z}$ otoczenia, a ich rola $\mathrm{w}$ procesie badania wynika z obopólnej zgody na przyjęcie społecznej konwencji relacji, jest umowna i de facto - wymienna.

Autorzy psychologicznych koncepcji poznania społecznego (Maruszewski 2003; Kofta 2005) wskazują, że ze względu na podobieństwo poznającego i poznawanego proces poznawania drugiego człowieka uruchamia szereg zmian zachowania obu zaangażowanych weń stron, wzajemną obserwację i autoprezentację, swoistą dwupodmiotowość poznania. Towarzyszy temu dużo większa łatwość dokonywania prywatnych, podmiotowych odniesień i interpretacji poznającego, pochodzących z wiedzy potocznej, popartej osobistym przekonaniem o słuszności. Człowiek to złożony i dynamicznie zmieniający się obiekt badania, proces jego poznania zatem wymaga uogólnień i selekcji obserwacji, a wnioskowanie często jest wieloetapowe, oparte na przyjęciu wstępnych założeń i uproszczeń.

Przetwarzanie informacji o tak złożonym obiekcie poznania angażuje znaczne zasoby poznającego, dlatego może przebiegać w sposób uproszczony i zautomatyzowany. Takie przetwarzanie informacji zwykle odbywa się poza świadomością jednostki, która nie snuje refleksji nad przebiegiem procesu, ani jego efektywnością. Opiera się ono na dostępnych schematach umysłowych, te zaś zależne są między innymi od wewnętrznych dyspozycji i stanów poznającego, jego uczuć, postaw, wcześniejszych operacji umysłowych (Greenwald, Banaji 1995; Hardin, Banaji 2010). Jednostka poznająca, także naukowiec, może kierować sposobem przetwarzania informacji, godząc się na szybkie i uproszczone przetwarzanie automatyczne bądź poddając autokrytyce kolejne kroki swojego działania poznawczego. Pytaniem pozostaje, jak szerokiej autoanalizie jednostka jest w stanie poddać przebieg własnych procesów poznawczych. Ograniczeniem może być zapewne zewnętrzny kontekst przetwarzania (np. dostępny czas), a także zakres pojęć używanych przez jednostkę i jej kulturową grupę odniesienia. O ile więc $\mathrm{w}$ danej społeczności nie zaistnieją warunki umożliwiające kwestionowanie rzeczy uznanych za oczywiste, o tyle mniej prawdopodobna (choć przecież niewykluczona) wydaje się możliwość dokonania refleksji przez pojedynczą osobę. Także badacza.

\section{Płeć jako szczególna kategoria w nauce}

Płeć uznawana jest za jedną z podstawowych kategorii, jakimi człowiek posługuje się w rozumieniu siebie, innych ludzi i relacji społecznych. Kategoria ta jest wcześnie nabywana $\mathrm{w}$ rozwoju, jest także jednym $z$ podstawowych elementów podmiotowej tożsamości (Cross, Marcus 2002). Jednocześnie odgrywa ona istotną rolę $\mathrm{w}$ kulturowo zróżnicowanych porządkach obyczajowych, moralnych i prawnych. Próby zakwestionowania obowiązującego w danej gru- 
pie sposobu używania kategorii płci często budzą negatywne emocje i opór, co jest zrozumiałe zważywszy na znaczenie tego pojęcia. Pociągają bowiem za sobą konieczność dokonania podmiotowych i społecznych rewizji: ponownego poszukiwania przez jednostki odpowiedzi na pytanie „Kim jestem?”; rekonstruowania społecznych regulacji kontaktów między ludźmi, ustalania podziałów zadań, ról, zakresów interpersonalnego wpływu. Zmiany te występują w procesach przemian kultur i społeczeństw, na co wskazuje historyczna analiza posługiwania się kategorią płci (por. Laqueur 1990; Kościańska 2014), są przy tym zmianami powolnymi oraz związanymi w silnymi reakcjami pojedynczych osób i grup.

W toku rozwoju idei konstrukcjonizmu społecznego podjęto szerokie analizy i zakwestionowano podstawowe pojęcia związane z płcią, takie jak męskość, kobiecość, oraz założenia dotyczące dychotomii płci i „naturalnej” różnicy między płciami. Po pierwsze, myśl konstrukcjonistyczna zakwestionowała biologiczny determinizm różnic między mężczyznami i kobietami, kładąc nacisk na kulturowo-społeczne procesy prowadzące do wytworzenia różnicy płci (Beall 2002). Umożliwiło to postawienie pytań o zakres znaczeniowy pojęcia płci i jego granice. Istotne znaczenie dla zaistnienia zmiany w sposobie używania tego terminu miało rozpowszechnienie przez drugą falę feminizmu w latach siedemdziesiątych XX wieku rozróżnienia na płeć biologiczną (sex) i społeczno-kulturową (gender) (Czarnacka 2014). Anglosaskie pojęcie gender, wcześniej oznaczające rodzaj gramatyczny, odniesiono do ról płciowych i psychicznych cech utożsamianych z kobiecością i męskością (Krasuska 2014). Dokonane rozróżnienie odegrało ogromną rolę $\mathrm{w}$ podważaniu stereotypów płci ${ }^{4}$. Płeć społeczno-kulturowa (czy też - jak chce Butler — płeć w ogóle) przestała być traktowana W nauce jako oczywista, dychotomiczna, uwarunkowana biologicznie zmienna.

Po drugie, idee konstrukcjonizmu społecznego dostarczyły także narzędzi do innych, szerszych analiz. Wśród nich znalazły się rozważania dotyczące kulturowego kontekstu zmian w sposobie rozumienia pojęcia płci, a więc skupione wokół pytania: Jakie warunki społeczne sprawiają, że pojęcie płci rozumiane / używane jest w określony sposób? Rozumienie pojęcia płci, jego wartościowanie czy sposób używania pojęć pomocniczych (takich jak naturalność czy przeznaczenie) uznano zatem za zależne od kontekstu społecznego. To w określonych warunkach społecznych nadawane płci znaczenia mogą zyskać na przykład status „praw natury”, co pociąga to za sobą istotne konsekwencje. Gdy pojęcie jest szeroko rozpowszechnione w grupie, staje się elementem „przymusu my-

\footnotetext{
${ }^{4}$ Należy wspomnieć, że w latach dziewięćdziesiątych rozróżnienie to doczekało się krytyki ze strony radykalnego konstruktywizmu Judith Butler (2008), według której odwoływanie się do płci biologicznej nie ma statusu wyjaśniania, lecz służy legitymizowaniu i reprodukowaniu różnicy płci. Z drugiej strony, współcześnie widoczny jest także coraz szerszy nurt alternatywnego sposobu opisywania płci biologicznej i zastępowania ujęcia dychotomicznego kontinuum płci (por. Fausto-Sterling 1993, 2000).
} 
ślowego" (pojęciem tak oczywistym, że nie poddawanym żadnej próbie kwestionowania) oraz —- kształtuje zwrotnie stosunki społeczne.

\section{Konstrukcja i dekonstrukcja kategorii płci} w myśli psychologicznej

Przedstawione konstatacje wywołały znaczący odzew w środowisku psychologicznym Stanów Zjednoczonych lat siedemdziesiątych i osiemdziesiątych ubiegłego wieku, uruchamiając procesy analizy sposobów używania pojęcia płci przez samych psychologów. Na przykład Jill Morawski (1985) prześledziła proces konstruowania w badaniach psychologicznych kategorii męskości / kobiecości, posługując się modelem dymorfizmu płciowego Lewisa M. Termana i Catharine Miles oraz modelem androgynii psychicznej Sandry Bem, i wykazała, iż oba podejścia przyczyniają się do umocnienia rozumienia tych pojęć jako uniwersalnych zespołów rzeczywistych cech.

Z kolei Rachel Hare-Mustin i Jeanne Marecek (1988) wyodrębniły dwa rodzaje błędów (bias) występujących w teoriach i badaniach psychologicznych: (1) błędy typu alfa dotyczące wyolbrzymiania różnicy między mężczyznami i kobietami tam, gdzie różnice te są minimalne lub statystycznie nieistotne; ten typ błędnego wnioskowania autorki uznały za rozpowszechniony w myśli psychologicznej, a jego ślady odnalazły zarówno w myśli psychoanalitycznej, jak i feministycznej; (2) błędy typu beta, występujące znacznie rzadziej, a polegające na minimalizowaniu lub pomijaniu różnic między mężczyznami i kobietami wynikających z odmiennego statusu społecznego i dostępu do władzy.

Pogłębienie świadomości środowiska psychologicznego co do obecności stereotypów i uprzedzeń związanych z płcią i ich wpływu na funkcjonowanie ludzi znalazło wyraz w podejmowanych przez Amerykańskie Towarzystwo Psychologiczne staraniach na rzecz ich wykorzenienia z praktyki badawczej i publikacyjnej. W roku 1977 na łamach „American Psychologist” towarzystwo opublikowało dokument Guidelines for Nonsexist Language in APA Journals. W roku 1988 powołało Ad Hoc Committee on Nonsexist Research, którego celem było ustalenie standardów prowadzenia badań naukowych uwrażliwionych na kwestię płci. Syntetycznie opracowane wytyczne dla badaczy opublikowano ponownie na łamach „American Psychologist” (Denmark, Russo, Frieze, Sechzer 1988). Tekst zawierał omówienie niedopatrzeń i błędów najczęściej występujących w psychologicznych publikacjach naukowych w odniesieniu do kolejnych etapów postępowania badawczego (zmodyfikowaną wersję tego opracowania, poszerzoną o etap upowszechniania wniosków z badań, przedstawia tabela 1).

Warto podkreślić, że działania APA wpisały się w szerszy nurt, zaznaczający się także w innych dziedzinach nauki (por. American Philosophical Association 1986) i kontynuowany współcześnie. Odzwierciedla się to w formułowaniu zaleceń na polu metodologii badań psychologicznych (APA 2010; Johnson, Greaves, Repta 2007; Chrisler, McCreary 2010) czy reguł stosowania neutral- 
Błędy i niedociągnięcia $\mathrm{w}$ przebiegu procesu badawczego związane $\mathrm{z}$ uproszczonym przetwarzaniem informacji o płci (w tym stereotypów płciowych)

\begin{tabular}{|c|c|}
\hline $\begin{array}{l}\text { Etap procesu } \\
\text { badawczego }\end{array}$ & $\begin{array}{l}\text { Przejawy zniekształcającego oddziaływania stereotypów płci } \\
\text { na badania psychologiczne }\end{array}$ \\
\hline $\begin{array}{l}\text { 1. Formułowanie pro- } \\
\text { blemów i hipotez ba- } \\
\text { dawczych }\end{array}$ & $\begin{array}{l}\text { - stereotypowy lub nieprecyzyjny sposób definiowania zmiennych } \\
\text { - traktowanie jako uniwersalnych pytań wywiedzionych z teorii/badań bazujących na } \\
\text { męskim doświadczeniu (androcentryzm), przy pominięciu doświadczenia kobiet } \\
\text { - wartościowanie znaczenia problemu badawczego w zależności od tego, której płci } \\
\text { dotyczy } \\
\text { - stawianie hipotez bazujących na: teoriach przyjmujących a priori założenia dotyczące } \\
\text { różnicy płci lub wynikach wcześniejszych badań opartych na błędnej metodologii } \\
\text { - stawianie hipotez na temat różnicy płci bez odwołania się do teorii lub wcześniej- } \\
\text { szych badań } \\
\text { - pomijanie znaczenia płci jako zmiennej ubocznej modyfikującej zależności między } \\
\text { innymi zmiennymi }\end{array}$ \\
\hline $\begin{array}{l}\text { 2. Przebieg badania i za- } \\
\text { stosowane metody } \\
\text { badawcze }\end{array}$ & $\begin{array}{l}\text { - dobór do próby badawczej wyłącznie osób jednej płci z uwagi na stereotypowe } \\
\text { kojarzenie z nią badanego zagadnienia lub dla wygody } \\
\text { - usuwanie osób danej płci z bazy danych, jeśli ich wyniki nie potwierdzają przyjętych } \\
\text { hipotez } \\
\text { - pomijanie czynnika płci osób badanych i eksperymentatorów oraz jego znaczenia } \\
\text { dla przebiegu badań i możliwych interakcji z innymi zmiennymi (np. statusem eko- } \\
\text { nomicznym, wykształceniem, rasą) } \\
\text { - stosowanie wskaźników zmiennych opracowanych na podstawie danych na temat } \\
\text { funkcjonowania przedstawicieli wyłącznie jednej płci } \\
\text { - stosowanie narzędzi skonstruowanych na podstawie stereotypów, co wpływa na } \\
\text { poziom lub sposób wykonania zadań przez badanych różnej płci } \\
\text { - stosowanie w odniesieniu do zmiennych lub w narzędziach badawczych języka styg- } \\
\text { matyzującego zachowania bądź sytuacje życiowe odbiegające od tradycyjnego wzor- } \\
\text { ca ról płciowych }\end{array}$ \\
\hline $\begin{array}{l}\text { 3. Analiza i interpreta- } \\
\text { cja wyników }\end{array}$ & $\begin{array}{l}\text { - prezentowanie przypadkowo odkrytych różnic między płciami jako znaczących, przy } \\
\text { - jednoczesnym przemilczaniu braku różnic } \\
\text { wyolbrzymianie różnic między płciami nie znajdujące uzasadnienia w otrzymanych } \\
\text { - niepełna analiza statystyczna różnic między płciami w przypadku, gdy otrzymany } \\
\text { wynik jest zgodny ze stereotypem } \\
\text { - arbitralne interpretowanie obserwowanych różnic jako zdeterminowanych biolo- } \\
\text { gicznie, przez czynniki wrodzone } \\
\text { - traktowanie różnic istotnych statystycznie jako różnic znaczących merytorycznie } \\
\text { - prezentowanie wyników w sposób ogólnikowy, sprzyjający potwierdzaniu stereo- } \\
\text { typów }\end{array}$ \\
\hline $\begin{array}{l}\text { 4. Sformułowanie wnio- } \\
\text { sków }\end{array}$ & $\begin{array}{l}\text { - generalizacja wyników uzyskanych w badaniu jednej płci na obie } \\
\text { - generalizacja różnicy między płciami uzyskanej w specyficznym zadaniu na różnicę } \\
\text { dotyczącą globalnych właściwości lub zdolności } \\
\text { - wykorzystywanie informacji o statystycznie istotnych różnicach między płciami ja- } \\
\text { ko podstawy do określania normatywnych dla danej płci możliwości, zadań i wy- } \\
\text { magań } \\
\text { - używanie stygmatyzującego języka }\end{array}$ \\
\hline $\begin{array}{l}\text { 5. Publikacja i populary- } \\
\text { zacja }\end{array}$ & $\begin{array}{l}\text { - nadawanie tytułu nieadekwatnego do treści artykułu (sugerującego możliwość sze- } \\
\text { rokich uogólnień) lub uruchamiającego stereotypowe skojarzenia } \\
\text { - popularyzacja wyników badań bądź koncepcji teoretycznych w sposób uproszczony, } \\
\text { potwierdzający stereotypy płciowe } \\
\text { - włączanie do tekstów popularnonaukowych treści stereotypowych, nie popartych } \\
\text { - piedzą naukową } \\
\text { nia prezentowąnych tez zawierających stereotypowe przekonania o płci }\end{array}$ \\
\hline
\end{tabular}


nego płciowo języka w dyskursie akademickim (np. Zentrale Gleichstellungsbeauftragte der Universität Potsdam 2012).

\section{KATEGORIA PŁCI W POLSKICH PUBLIKACJACH PSYCHOLOGICZNYCH - ANALIZA WYBRANYCH PRZYKŁADÓW}

Analiza historyczno-kulturowych kontekstów uprawiania nauki oraz inicjatywy zachodniego środowiska psychologicznego stały się pretekstem do postawienia pytania o to, jak w polskich publikacjach $z$ zakresu psychologii konstruowana jest i używana kategoria płci. Potrzebę takiej analizy uzasadnia szeroki zakres oddziaływania kategorii płci w rodzimej kulturze, odzwierciedlony w języku polskim oraz obyczajach i normach prawnych określających wzorce relacji międzyludzkich w kontekście płci. O znaczeniu tej kategorii świadczy między innymi fakt wybrania przez językoznawców Fundacji Języka Polskiego słowa gender słowem roku $2013 \mathrm{w}$ polskiej debacie publicznej ${ }^{5}$. Warto podkreślić, iż w debacie tej głos zabierali także psychologowie, powołując się na własną rolę zawodową.

Przedstawione niżej przykłady zostały wytypowane w wyniku krytycznego przeglądu wybranych polskich psychologicznych tekstów naukowych pod kątem odpowiedzi na postawione wcześniej pytanie o sposób konstruowania kategorii płci w kontekście płciowych stereotypów. Przegląd ten obejmuje opublikowane po 2000 roku artykuły z czasopism naukowych oraz wybrane pozycje książkowe (wyłącznie prace recenzowane). W części tych opracowań płeć stanowi podstawowy obszar zainteresowań, w innych jest wątkiem pobocznym. Rok 2000 został wybrany nieprzypadkowo - właśnie wtedy został opublikowny długo oczekiwany, trzytomowy, podręcznik akademicki Psychologia pod redakcją Jana Strelaua. Można zakładać, że publikacja ta znacząco wpłynęła na proces kształcenia studentów i studentek, a także wyznaczyła nowe standardy w zakresie popularyzowania wiedzy psychologicznej. W tym samym roku ukazała się także inna istotna publikacja podręcznikowa - praca zbiorowa pod redakcją Jerzego Brzezińskiego i Małgorzaty Toeplitz-Winiewskiej Etyczne dylematy psychologii. Rozwijano w niej wprowadzony w podręczniku wątek etyki pracy psychologicznej, w tym etyki prowadzenia badań oraz popularyzowania wiedzy.

Przeprowadzona analiza wpisuje się w opisany wcześniej drugi poziom rozważań konstrukcjonistycznych, a więc koresponduje z pytaniem o to, jak przebiega proces konstruowania pojęcia płci przez członków grupy społecznej (tu:

\footnotetext{
${ }^{5}$ Istotnym wydarzeniem, które wywołało w Polsce społeczną dyskusję wokół tematyki gender, było podpisanie w grudniu 2012 roku przez polski rząd Konwencji Rady Europy o zapobieganiu i zwalczaniu przemocy wobec kobiet i przemocy domowej. Prace nad jej ratyfikacją stały się przyczynkiem do szerokich i budzących silne emocje dyskusji społecznych, zwłaszcza w związku z zawartymi $\mathrm{w}$ treści dokumentu odniesieniami do pojęć takich jak: płeć społeczno-kulturowa czy stereotypy płci.
} 
psychologów-naukowców). Analiza ta obejmowała wybrany aspekt — spójność ze stereotypami płciowymi. Nie podejmujemy tutaj rozważań z obszaru podstawowego, a więc tego, czym w swej istocie płeć jest, czy lub w jakim stopniu podlega uwarunkowaniom biologicznym lub społeczno-kulturowym. Pragniemy zaprosić czytelników do refleksji nad przykładami tego, w jaki sposób w psychologicznych tekstach naukowych kategoria płci jest opisywana i wyjaśniana, jak tworzy pojęcia i narrację dotyczącą tego zagadnienia.

Chcemy podkreślić, że prezentowany przegląd z założenia nie jest systematyczny, a dobór tekstów (poza zasygnalizowanymi bardzo ogólnymi kryteriami) ma charakter arbitralny i obejmuje głównie prace mieszczące się w kręgu naszych zainteresowań. Teoretyczną podstawę analizy stanowi myśl konstrukcjonistyczna, a jej struktura opiera się na zaczerpniętym $z$ literatury katalogu przejawów powielania stereotypów płci na różnych etapach procesu badawczego (zob. tabela 1). Przez celowy wybór przykładów negatywnych mamy nadzieję zwrócić uwagę na problem dotychczas w polskim piśmiennictwie nie podejmowany wprost, a - naszym zdaniem - nader istotny z punktu widzenia standardów pracy naukowej i jej wpływu na praktykę społeczną.

\section{Formułowanie problemu i hipotez badawczych}

W odniesieniu do pierwszego etapu procesu badawczego zalecenia APA z 1986 roku w większości dotyczą rażących nadużyć, które przy zachowaniu podstawowych zasad rzetelności i etyki prowadzenia badań naukowych wydają się stosunkowo łatwe do uniknięcia. Mimo to kwestie związane z teoretycznym opracowaniem zagadnienia, definiowaniem zmiennych bądź formułowaniem problemu mogą okazać się szczególnie wrażliwe na oddziaływanie potocznego, stereotypowego spostrzegania płci, jeżeli badacz nie zadba o spójność teoretyczną, precyzję i krytycyzm w odniesieniu do przyjętych założeń.

Jako pierwszy przykład może posłużyć tekst Tożsamość płciowa chłopców wychowywanych przez samotne matki opublikowany w kwartalniku „Małżeństwo i Rodzina" 6 (Napora 2003). Główną jego tezą jest uznanie sprawowania opieki nad dzieckiem wyłącznie przez matkę za czynnik ryzyka zaburzeń prawidłowego rozwoju tożsamości płciowej syna. Naszą pierwszą wątpliwość budzi nieprecyzyjna definicja podstawowego pojęcia „tożsamość płciowa”. Co prawda, w pierwszym zdaniu wprowadzenia teoretycznego czytamy: „Pojęcie tożsamości płciowej odnosi się do wewnątrzosobowych procesów psychologicznych tworzących strukturę naszego JA" (s. 34), jednak definicja ta dotyczy tożsamo-

\footnotetext{
${ }^{6}$ Ten sam artykuł $\mathrm{w}$ nieznacznie zmienionej formie ukazał się pod sugestywnym tytułem Bez kompasu, czyli płeć psychologiczna chłopców wychowywanych przez samotne matki $\mathrm{w}$ internetowym czasopiśmie „Niebieska Linia”, będącym organem Polskiego Towarzystwa Psychologicznego (http://www.niebieskalinia.pl/pismo/wydania/dostepne-artykuly/4468-bez-kompasu-czyliplec-psychologiczna-chlopcow-wychowywanych-przez-samotne-matki).
} 
ści szeroko rozumianej, a tekst źródłowy, na który powołuje się autorka: Chlewiński 1995, nie dotyczy tożsamości płciowej. Autorka zauważa dalej: „Płeć, płciowość, tożsamość - różne jej rodzaje - definiowane są na wiele sposobów i wielu autorów poświęca im swoją uwagę" (s. 34). Swobodnie zestawia pojęcia psychologii poznawczej („Podstawa tożsamości płciowej tworzy strukturę JA”) i psychoanalizy („męskość i kobiecość według psychoanalizy wiąże się z osiągnięciem fazy genitalnej — pełnej identyfikacji z własnym, biologicznym wyposażeniem"), nie porządkuje ich jednak ani nie deklaruje wprost, który nurt stanowi podstawę jej badań. Konstatuje jedynie - naszym zdaniem, nieprecyzyjnie - iż „ "tożsamość płciowa» to utożsamianie się z płcią męską bądź żeńską" (s. 35).

Uwagę zwraca też ogólnikowy sposób uzasadnienia podstawowej hipotezy. Autorka pisze na przykład: „Autorzy podejmujący to zagadnienie są zgod$\mathrm{ni}$, że prawidłowa identyfikacja $\mathrm{z}$ płcią może przebiegać tylko $\mathrm{w}$ warunkach, kiedy dziecko ma styczność zarówno z wzorcami męskości jak i kobiecości" (s. 34) - nie przytacza jednak, jakich autorów ma na uwadze. W końcu odwołuje się do podzielanej społecznie wiedzy związanej z rolą ojca, pisząc: „Ojciec - zgodnie z pewnym utrwalonym stereotypem [podkr. J.W. i M.Z.J.] — stawiając dziecku wymagania, uczy je bardziej dojrzałego sposobu zdobywania miłości: poprzez doskonalenie się. Dostarcza tak potrzebnego w wychowaniu autorytetu, nagradza i karze, wprowadza w środowisko pozarodzinne. Jest pośrednikiem pomiędzy bezpiecznym światem ciepłych uczuć stworzonych przez matkę a światem zewnętrznym - często budzącym lęk" (s. 35). Twierdzenia te przedstawione są jako fakty, mimo że mają raczej status uogólnień i interpretacji opartych na założeniach jednego z paradygmatów teorii psychoanalitycznej.

Naszym zdaniem, niedociągnięcia $\mathrm{w}$ definiowaniu podstawowych pojęć i uzasadnianiu hipotez badawczych skutkują dyskusyjnym wnioskowaniem o trudnościach chłopców w budowie tożsamości płciowej na podstawie różnic w wynikach uzyskanych za pomocą Inwentarza Płci Psychologicznej (Kuczyńska 1992). Jest to narzędzie, które pozwala co prawda ustalić, w jakim stopniu osoba badana podczas samookreślania korzysta ze schematu poznawczego męskości i kobiecości, odzwierciedlającego kulturowo akceptowany, stereotypowy wzorzec, nie stanowi to jednak pełnego obrazu składowych tożsamości płciowej. Tymczasem w tekście znajdujemy interpretację wyników w kategoriach niepewności tożsamości płciowej, rozumianej jako identyfikacja z płcią biologiczną.

Podążając za tokiem wywodu autorki można zyskać przekonanie o słuszności postawionej przez nią wyjściowej tezy, mimo że (a może właśnie dlatego) twierdzenia, które formułuje, są ogólnikowe, a pojęcia odnoszą się do różnych paradygmatów. W efekcie czytelnik może się odwoływać do wiedzy potocznej, przekonań tak podstawowych, że nie podawanych w wątpliwość. Tymczasem sposób narracji, a ponadto opublikowanie tekstu w czasopiśmie 
naukowym, nadaje zaprezentowanym treściom znamiona wiedzy zweryfikowanej, „prawdy”.

Innym, bardziej subtelnym zaniechaniem jest stawianie hipotez dotyczących różnic płciowych bez wyraźnie wyartykułowanych przesłanek. Tekst pt. Zachowania ryzykowne młodzieży gimnazjalnej, opublikowany w „Psychologii Rozwojowej” (Siudem 2013), jest artykułem empirycznym, mającym na celu „poznanie i określenie struktury zachowań ryzykownych młodzieży” (s. 72). W teoretycznym wprowadzeniu autorka przedstawia informacje na temat zachowań ryzykownych, ich funkcji i etiologii. Następnie formułuje problemy badawcze (i odpowiadające im hipotezy) dotyczące: (1) częstotliwości występowania zachowań ryzykownych, (2) form przejawianych zachowań oraz (3) związku między zachowaniami ryzykownymi a płcią osób badanych. Stawia też tezę: „Płeć różnicuje zachowania ryzykowne pod względem ich częstości i struktury" (s. 73), co może zaskakiwać wobec całkowitego pominięcia tej kwestii we wstępie. Sformułowanie to postrzegamy jako odzwierciedlenie przyjętego implicite założenia o różnicy między płciami, z pominięciem konieczności jego uzasadnienia na gruncie nauki. Autorka nie miałaby trudności ze znalezieniem publikacji wskazujących na różnice między płciami w zakresie przejawiania zachowań agresywnych, prozdrowotnych i autodestruktywnych, co pozwoliłoby uargumentować i uszczegółowić postawioną tezę, rzecz w tym jednak, że hipotezy dotyczące różnic między kobietami a mężczyznami tak mocno wpisują się w zdychotomizowane postrzeganie płci w naszej kulturze, że zdają się oczywiste i nie wymagające uzasadnień.

Zdarzają się także przykłady milczącej rezygnacji z kontrolowania znaczenia zmiennej płci w badaniu, nawet wówczas, gdy jej uwzględnienie wydaje się uzasadnione. Artykuł pt. Praca zawodowa jako obszar misji społecznej, opublikowany w „Psychologii Społecznej” (Czerw, Borkowska 2010), dotyczy pytań o związki między odczuwaniem misji a wykonywanym zawodem. Autorki porównują osoby pracujące $w$ zawodach $z$ misją społeczną i bez niej, jednak nie wiadomo, czy proporcje kobiet i mężczyzn w obu grupach są zbliżone. Zważywszy, że w grupie wykonującej zawody z misją społeczną znaleźli się: "pracownicy służby zdrowia (lekarze i pielęgniarki, $N=78)$ oraz nauczyciele $(N=119)$ ", a wśród zawodów bez misji ,projektanci $(N=35)$, informatycy $(N=42)$, sprzedawcy $(N=28)$, księgowi $(N=30)$, kierownicy niższych szczebli w różnych organizacjach $(N=40)$ " (s. 308), pytanie o rozkład i znaczenie płci w analizach wydaje się uzasadnione.

Uwzględnienie płci w projekcie badawczym bądź jej pominięcie może mieć poważne konsekwencje dla wnioskowania o zależnościach między zmiennymi. Nie wydaje się zasadne, by płeć była włączana do modelu zmiennych w każdym projekcie badawczym, uważamy jednak, iż jest to zmienna tak znacząca i potencjalnie interferująca $z$ innymi, że świadome i oparte na analizie literatury podejmowanie decyzji co do jej uwzględnienia powinno być standardem badań psychologicznych (por. Johnson, Greaves, Repta 2007). 


\section{Przebieg badania i zastosowane metody badawcze}

Niedociągnięcia metodologiczne będące efektem wpływu potocznego sposobu rozumienia płci mogą dotyczyć także doboru próby badawczej, narzędzi do pomiaru oraz organizacji przebiegu badania. Uchybienia tego etapu badawczego odegrały znaczącą rolę $\mathrm{w}$ historii psychologii ${ }^{7}$, co - jak zakładamy uświadomiło badaczom wagę zagadnienia. Nawet jeśli płeć nie ma znaczenia dla zależności między zmiennymi, to zebranie i sprawozdanie informacji o niej ułatwia trafne generalizowanie i korzystanie z prezentowanych wyników, na przykład $w$ późniejszych metaanalizach (płeć jest jednym z potencjalnych źródeł heterogeniczności wyników badań i jako taka może oddziaływać na wynik metaanalizy; zob. Kleka 2011).

Innym ważnym $\mathrm{w}$ tym miejscu zagadnieniem jest dbałość o trafny pomiar zmiennej w zbiorowościach obu badanych płci - jednolity (jeśli dla badanej zmiennej kategoria płci nie ma znaczenia) lub analogiczny (gdy płeć ma znaczenie dla operacjonalizacji i dokonywania pomiaru). Podobnie - niezbędne jest uwzględnianie w procedurach badawczych wpływu norm regulujących zachowania płciowe badaczy i badanych (np. związanych $z$ dystansem fizycznym i psychologicznym, autoprezentacją itp.).

Przykładem wartym przytoczenia w tym miejscu jest publikacja książkowa Profilaktyka ryzykownych zachowań seksualnych mtodzieży, wydana przez Wydawnictwo Naukowe Scholar (Grzelak 2006). Praca koncentruje się wokół tytułowej tematyki i efektywności programu profilaktycznego „Płciowość i Odpowiedzialność Nastolatków”. Badanie efektywności programu zostało zaprojektowane $\mathrm{w}$ planie eksperymentalnym, a jako narzędzie badawcze stosowany był samoopisowy kwestionariusz.

W programie podjęto temat zróżnicowania oddziaływań wobec dziewcząt i chłopców i „pomiaru niektórych zmiennych dokonywano tylko dla jednej z płci" (s. 162). Wyłącznie u dziewcząt mierzono takie zmienne jak: wiedza o objawach płodności, związkach między cyklem hormonalnym a nastrojami u kobiet wraz z umiejętnością identyfikacji tych związków we własnym samopoczuciu, umiejętność rozpoznawania płodności i przewidywania miesiączki we własnym cyklu owulacyjnym. U chłopców wyłącznie mierzono: wiedzę o możliwości kontrolowania reakcji seksualnej u mężczyzny, o aseksualnych przyczynach erekcji, intencję unikania pobudzenia seksualnego (s. 162-163). Dane dotyczące funkcjonowania płciowego i seksualnego nastolatków były zbierane zatem w sposób wybiórczy: u dziewcząt dotyczyło to zagadnień związanych z funkcją prokreacyjną, badanie nie zakładało pomiaru analogicz-

\footnotetext{
${ }^{7} \mathrm{Na}$ przykład badania rozwoju moralnego Kohlberga w pierwotnej formie doprowadziły do ustalenia androcentrycznego standardu, a w konsekwencji do nieadekwatnej oceny wyników uzyskiwanych przez kobiety — świadczących jakoby o ich niższym poziomie rozwoju moralnego (Brannon 2002).
} 
nej zmiennej u chłopców, na przykład samoświadomości płodności i czynników na nią wpływających (przy uwzględnieniu odmienności prokreacyjnej kobiet i mężczyzn; badano jedynie postawę wobec własnej płodności). Wiedzę na temat reaktywności seksualnej i możliwości wpływu na nią badano wyłącznie u chłopców, w żaden sposób zaś nie poruszano tej kwestii w grupie dziewcząt. Uzasadnienie zebrania tak wybiórczych danych o wskazanych aspektach funkcjonowania seksualnego młodzieży jest niewystarczające i może przyczyniać się do podtrzymywania stereotypowego obrazu seksualności dziewcząt i chłopców, opartego na tzw. podwójnym standardzie (Bancroft 2013).

Kolejną kwestią jest dobór wskaźników badanych zmiennych. Ponieważ założono, że dojrzewanie biologiczne „może wpływać na recepcję programu PiON" (s. 162), w kwestionariuszu zawarto pytania dotyczące jego przebiegu. W wersji dla dziewcząt pytano, czy badana rozpoczęła miesiączkowanie, od informacji tej zależało udzielanie odpowiedzi na dalsze pytania dotyczące samoobserwacji cyklu owulacyjnego oraz zmian nastrojów. W wersji dla chłopców pytano o mutację, a twierdząca odpowiedź pozwalała przejść do pytań związanych z samoobserwacją reaktywności seksualnej (w postaci erekcji) oraz wpływania na nią. Autor nie wyjaśnia, czego wskaźnikiem miała być w tym badaniu miesiączka i mutacja. Jeśli traktować je jako wskaźniki tej samej zmiennej (zaawansowania zmian biologicznego dojrzewania), co sugeruje nadanie im podobnej funkcji w kwestionariuszu i wskazana wyżej uwaga autora, to należy zwrócić uwagę, że nie są one wskaźnikami analogicznymi ani z punktu widzenia przebiegu procesu dojrzewania (inny moment występowania w strukturze kolejnych zmian), ani z perspektywy ich społecznego odbioru, a tym samym gotowości badanych do ujawniania (prywatne / publiczne, ukryte / jawne).

W analizowanym kwestionariuszu weryfikowano między innymi wiedzę na temat związku nastroju i zmian hormonalnych w toku cyklu owulacyjnego kobiet. Wszystkim nastolatkom zadawano pytanie:

„Wiadomo, że hormony wpływają na nastroje kobiet w dniach przed miesiączką. W pozostałych dniach cyklu hormony żeńskie najczęściej:

1. Działają uspokajająco w pierwszej i drugiej części cyklu (czyli przed jajeczkowaniem i po nim).

2. Powodują większą drażliwość w pierwszej i drugiej części cyklu.

3. Powodują skupienie na sobie w pierwszej części cyklu, a poczucie otwartości na innych w drugiej.

4. Dają poczucie otwartości na innych w pierwszej części cyklu, a skupienie na sobie $z$ drugiej.

5. Nie mają wpływu na nastroje i uczucia kobiet.

6. Nie wiem" (s. 299).

Konstrukcja pytania oparta jest na wprowadzonym we wstępie apriorycznym założeniu dotyczącym bezpośredniego wpływu hormonów na nastój u kobiet (wyłącznie). Nie jest tak w świetle współczesnej wiedzy, wskazującej na duże różnice wśród kobiet, a także różne znaczenia przypisywane tej zależno- 
ści (por. Bancroft 2013). Dostępny katalog odpowiedzi zaś uniemożliwia wyrażenie swojego zdania osobom, które mają wiedzę o możliwym zróżnicowaniu indywidualnym $\mathrm{w}$ zakresie tej zależności lub postrzegają ją w inny sposób.

Źródłem nieścisłości w opisach zachowań mężczyzn i kobiet może też być nieadekwatny dobór narzędzi badawczych, jak w badaniu zaprezentowanym $\mathrm{w}$ tekście pt. Przywiazanie $i$ satysfakcja $z$ realizacji zadań rozwojowych $w$ bliskich zwiazkach a zachowania agresywne między partnerami opublikowany $\mathrm{w}$ „Psychologii Rozwojowej" (Malina, Suwalska 2012). Jakkolwiek tytuł sugeruje, że jedną ze zmiennych jest agresja wobec partnera / partnerki w związku, to do pomiaru posłużył Kwestionariusz Agresji A. Bussa i M. Perry’ego (BPAQ), który jest narzędziem badającym uogólniony poziom agresywności (w tym: agresję fizyczną, werbalną, gniew i wrogość) bez wskazania, wobec kogo agresja jest kierowana. W efekcie stwierdzono większe natężenie agresji fizycznej w grupie mężczyzn w porównaniu $\mathrm{z}$ kobietami, a także brak zróżnicowania w nasileniu agresji w różnych typach związków (małżeńskich, narzeczeńskich, kohabitacyjnych). Założenie implicite, że ogólne natężenie agresji znajduje odzwierciedlenie w zachowaniach agresywnych między partnerami, wydaje się jednak przyjęte na wyrost i może prowadzić do błędnego wnioskowania.

\section{Analiza i interpretacja wyników}

Uznane $\mathrm{w}$ danej dziedzinie nauki standardy metodologiczne wyznaczają metody uogólniania obserwacji oraz odnoszenia ich we wnioskowaniu do pojęć teoretycznych. Dotyczą one między innymi warunków wskazywania na istnienie różnic i podobieństw między badanymi, wyjaśniania związków tych różnic / podobieństw $z$ innymi właściwościami, także adekwatnego w proporcjach omówienia poszczególnych wyników. Choć wydaje się, że te działania naukowca są dość ściśle określone przez standardy metodologiczne i reguły wnioskowania statystycznego, na ich pomijanie istotny wpływ mogą mieć stereotypy płciowe, co empirycznie wykazała Kinga Piber-Dąbrowska (2008).

Przykładem nieuprawnionej interpretacji uzyskanych danych jest przedstawione wcześniej badanie Tożsamość płciowa chłopców wychowywanych przez samotne matki (Napora 2003). Autorka włączyła w tekst opracowania tabelę, w której zaprezentowała miary średniej i odchylenia standardowego dla wymiaru kobiecości i męskości Inwentarza Płci Psychologicznej w grupie chłopców wychowywanych wyłącznie przez matki (dla skali kobiecości i męskości odpowiednio: $M=47,74 ; S D=7,6 ; M=46,02 ; S D=10,87)$ i w grupie chłopców wychowywanych przez matki i ojców (dla skali kobiecości i męskości odpowiednio: $M=49,80 ; S D=6,46 ; M=49,50 ; S D=6,66)$. Wyniki te nie zostały poddane testowaniu pod względem istotności różnic. Na podstawie różnic w zakresie odchylenia standardowego autorka wnioskuje: „W grupie opisowej zarówno w Skali Kobiecości jak i Męskości występują duże wahania w uzyskanych wynikach. Natomiast w grupie kontrolnej wartości odchylenia są niższe 
i bardziej zbliżone do siebie, a badani z tej grupy określają siebie w sposób bardziej zdecydowany, przypisując cechom wartości skrajne" (s. 36). Przypomnijmy, że odchylenie standardowe to miara zróżnicowania wyników w grupie (Ferguson, Takane 1997), na jego podstawie można zatem jedynie wnioskować o spójności wyników grupy, nie zaś o indywidualnych cechach, takich jak określanie siebie w zdecydowany sposób.

Inny przykład nieuprawnionego sposobu prezentowania wyników znajdujemy w artykule zatytułowanym Charakter więzi rodzinnych oraz uwarunkowania ich kształtowania się w sytuacji okołoporodowej opublikowany w „Psychologii Rozwojowej" (Kaźmierczak i in. 2012). W jednym z dwóch badań na etapie prezentowania wyników - niejako dodatkowo (bez wprowadzania tej kwestii od początku artykułu) - autorki zadają pytanie o różnice między płciami w zakresie postrzegania przez badanych rodziców spójności rodziny, diady partnerskiej oraz relacji matka-dziecko (badania prowadzono w drugiej i trzeciej dobie po porodzie). Jakkolwiek analizy „nie wykazały istotnych różnic pomiędzy badanymi matkami a ojcami w zakresie postrzeganej spójności rodziny czy też relacji matka-dziecko" (s. 32), to wynik świadczący o różnicy między płciami w zakresie oceny spójności diady na poziomie trendu (przy $p<0,1)$ został zaprezentowany w tabeli i omówiony. Autorki uznają go za „ciekawy i inspirujący do prowadzenia dalszych badań" (s. 32) na większej próbie w celu sprawdzenia istotności tej różnicy. Podany przykład obrazuje, jak subtelnie może przebiegać konstruowanie różnicy płci między mężczyznami a kobietami. Wynik świadczący o braku różnic zostaje jedynie zrelacjonowany, choć zważywszy na specyficzny moment prowadzenia badania w życiu rodziny, wydaje się nam wart podkreślenia. Poświęcenie miejsca w tekście (zamieszczenie odrębnej tabeli, obszerniejsza wypowiedź) wynikowi wskazującemu na różnicę między płciami, istotnemu „na poziomie trendu”, oraz uznanie go za ciekawy i wart dalszych badań nadaje mu szczególne znaczenie, pozostawiając wrażenie wagi różnicy płci. Dzieje się tak, mimo że zgodnie z zasadami metodologii neopozytywistycznej zarówno potwierdzenie, jak i odrzucenie hipotezy zerowej powinno być traktowane jako równie wartościowe (Brzeziński 2004).

Sposób prezentowania i omawiania wyników należy do formalnych właściwości tekstu, które oddziałują na odbiór tych treści obok deklaracji składanych explicite, takich jak odniesienia do pojęć sugerujących wrodzony lub biologiczny charakter różnic między płciami, przy pominięciu czynników o charakterze społecznym. W cytowanym już tekście Maliny i Suwalskiej (2012) znajdujemy następującą interpretację wyniku wskazującego na większą agresywność fizyczną mężczyzn: „Tłumaczy się to wyższym poziomem testosteronu, który przyczynia się do tego, że mężczyźni popełniają więcej zbrodni, są bardziej agresywni i skłonni do walki" (s. 83). Odwołanie się wyłącznie do wyjaśnienia biologicznego wpisuje się $\mathrm{w}$ deterministyczne, biologistyczne myślenie o płci i różnicach między kobietami a mężczyznami, i tym samym potwierdza słuszność takiego poglądu i przemilcza kwestię możliwych oddziaływań społecznych 
związanych z przyzwoleniem czy wzmacnianiem agresywności chłopców i mężczyzn. Z kolei w tekście Kaźmierczak i zespołu (2012) autorki opisując proces tworzenia więzi z dzieckiem stwierdzają: „pomimo istnienia bazy w postaci instynktu macierzyńskiego niektórzy rodzice mogą doświadczać przykrych emocji (smutek, strach), które nie pozwalają im całkowicie pozytywnie odnosić się do obecności noworodka i włączenia go w system rodzinny" (s. 36). Jest to przykład powołania się na „instynkt macierzyński”, pojęcie szeroko krytykowane (zob. np. Macintyre 1982). Jego zastosowanie w tym miejscu nie wnosi, naszym zdaniem, nowej treści do omówienia zaprezentowanych wyników, bo nie było przedmiotem szerszych analiz ani teoretycznych, ani empirycznych. Informuje natomiast o przyjętym przez badaczki założeniu - spójnym z potocznymi, utartymi poglądami - o wrodzonej dyspozycji kobiet do otaczania miłością swojego dziecka. Legitymizuje je publikacja w tekście naukowym.

\section{Sformułowanie wniosków}

Celem etapu formułowania wniosków badawczych jest wykazanie znaczenia uzyskanych wyników dla szerszej teorii eksplorowanego zagadnienia (np. uzasadnienie potrzeby dokonania rewizji koncepcji, prowadzenia dalszych badań) oraz sformułowanie zaleceń dla praktyki psychologicznej. Błędami na tym etapie są: nieuzasadnione uogólnianie wyników badania pomijające ograniczenia próby badawczej czy zastosowania wybiórczych wskaźników, budowanie nieuprawnionych zaleceń na temat możliwości osób określonej płci bądź używanie we wnioskach sformułowań stygmatyzujących.

We wspomnianym wcześniej tekście poświęconym badaniu ryzykownych zachowań młodzieży (Siudem 2013) autorka formułując wnioski stwierdza, że w grupie badawczej więcej dziewcząt niż chłopców paliło papierosy z częstotliwością od jednego do pięciu papierosów dziennie. W dyskusji wynik ten jest przywołany trzykrotnie (między innymi w ostatnim zdaniu artykułu jako główny obszar różnic między chłopcami a dziewczętami), jest też poddany rozbudowanej interpretacji: „Zwraca uwagę fakt, iż w grupie gimnazjalistów palących z częstotliwością "1-5 papierosów dziennie» jest istotnie więcej palących dziewcząt. Takich różnic nie zaobserwowano ani $\mathrm{w}$ badaniach ESPAD w 2007 i w 2009 roku, ani w badaniach HBSC 2010. [...] Można przypuszczać, iż jest to związane ze zmieniającymi się rolami społecznymi w zakresie płci, co powoduje, że w wielu sytuacjach kobiety (dziewczęta) chcą dorównać mężczyznom (chłopcom). Ponadto potoczne obserwacje funkcjonowania młodzieży gimnazjalnej wskazują, iż dziewczęta coraz częściej przejmują inicjatywę, np. proponują chłopcom wchodzenie w bliskie, intymne relacje, takie jak: przyjaźń czy tzw. chodzenie ze sobą" (s. 82). Powyższe wnioskowanie budzi następujące wątpliwości: (1) autorka odnosi wyniki swojego badania $(\mathrm{N}=158$ osób) do wcześniejszych badań prowadzonych na kilkakrotnie większych populacjach (np. w badaniu ESPAD 2007 w Polsce wzięło udział 
2120 osób $\left.^{8}\right)$ - można więc zastanawiać się, czy zaobserwowana różnica międzypłciami nie wynika ze specyfiki badanej próby; (2) jeśli różnica dotyczyłaby zmiany, jaka dokonała się w ciągu trzech lat (ostatnie badanie HBSC pochodzi z 2010), to można stawiać pytanie, czy zmiany kulturowe związane z rolami społecznymi zaszłyby tak szybko; (3) czy potoczne obserwacje stanowią wystarczające uzasadnienie interpretacji wyników; (4) dlaczego autorka pomija w interpretacji pozostałe różnice zaobserwowane między chłopcami a dziewczętami (częstsze używanie przez dziewczęta leków uspokajających; częstsze używanie przez chłopców marihuany i haszyszu oraz przejawianie zachowań agresywnych).

Sposób zaprezentowania i interpretacji różnic (lub ich braku) wyników dotyczących przejawiania agresji i przemocy werbalnej zasługuje, naszym zdaniem, na odrębny komentarz. Częstsze występowanie wśród chłopców czterech z sześciu kategorii zachowań agresywnych nie zostało poddane dyskusji. Relacja na ich temat nosi wyraźnie marginalny charakter. Autorka za „niepokojący fakt” uznaje, że "najczęstszym jej przejawem [agresji] u obojga płci jest stosowanie wyzwisk i obelg, którymi posługuje się 100\% badanej populacji gimnazjalistów" (s. 83), jednak już kilkakrotnie (sic!) częstsze stosowanie przez chłopców gróźb, opowiadanie nieprawdziwych/poniżających historii na czyjś temat, zmuszanie kogoś do robienia rzeczy niechcianych czy też wypisywanie obraźliwych sms-ów/e-maili nie jest opatrzone żadnym komentarzem czy interpretacją. Ze względu na dysproporcję akcentowania wagi różnic między płciami w zakresie poszczególnych badanych zachowań oraz wartościowanie ich przez opatrywanie (bądź nie) stosownym komentarzem, można nabrać przekonania, że w tekście przyjęto implicite tezę mówiącą, iż przejawianie zachowań ryzykownych przez chłopców jest normatywne, a przez dziewczęta nie.

W tym miejscu warto także przywołać cytowane wyżej badanie profilaktyki ryzykownych zachowań seksualnych młodzieży (Grzelak 2006). Obejmowało ono między innymi pomiar deklarowanej przez młodych ludzi nadziei na stworzenie w przyszłości szczęśliwego i trwałego związku. Wyniki wskazały na przejściowy wzrost poziomu tak zdefiniowanej nadziei u chłopców oraz trwałe zmniejszenie u dziewcząt biorących udział w programie PiON. Autor badania opisuje i interpretuje te wyniki w sposób następujący: „Z epidemiologicznego punktu widzenia wynik uzyskany dla chłopców jest korzystny, a dla dziewcząt niekorzystny. Nie jest pewne, czy efekt zaobserwowany u dziewcząt oznacza, że straciły one część nadziei na przyszłość. Mogły po prostu zdać sobie sprawę, że zbudowanie trwałego i szczęśliwego związku przychodzi nie bez wysiłku i nie jest wcale łatwe" (s. 230). W innym miejscu pracy autor pisze o tym samym wyniku: „Być może zatem program PiON zachęcił je do refleksji nad budowa-

\footnotetext{
${ }^{8}$ http://www.espad.org/Uploads/ESPAD_reports/2007/The_2007_ESPAD_Report-FULL_0910 06.pdf
} 
niem związków i pokazał, że nie jest to tak proste, jak ukazują to kolorowe czasopisma" (s. 260). Interpretacja ta, jak się wydaje, mocno wykracza poza ramy teoretyczne projektu badawczego, ponadto ma charakter stygmatyzujący dziewczęta.

\section{Publikacja i popularyzacja wniosków pochodzących z badań}

Choć źródłowe opracowanie APA, stanowiące inspirację do naszych analiz, nie odnosiło się do kwestii upowszechniania wyników badań, uzasadnienia dla poświęcenia uwagi temu etapowi dostarcza refleksja nad wpływem wiedzy naukowej na konstrukcję wiedzy potocznej. Znaczenie błędów tego etapu wydaje się szczególne, jeśli weźmiemy pod uwagę zrozumiałe ograniczenia umiejętności krytycznego odbioru publikacji przez czytelników nie będących naukowcami.

Przykładem wartym omówienia jest w tym kontekście praca pt. Już nie kobieta? Samoocena atrakcyjności ciała starzejących się wdów opublikowana w czasopiśmie „Dyskursy Młodych Andragogów” (Niewiedział 2014). Artykuł przedstawia wyniki badań empirycznych dotyczących subiektywnej atrakcyjności fizycznej, seksualnej, troski o wagę i sprawności fizycznej u wdów w wieku 61-78 lat. Autorka badania zastosowała kwestionariusz, za pomocą którego kobiety oceniały swoją postawę wobec wybranych części ciała i jego funkcji. Niejasne jest, na jakiej podstawie odniosła ona uzyskane wyniki do pojęcia kobiecości i społecznych stereotypów starych kobiet, którym zresztą poświęciła sporo miejsca we wprowadzeniu do artykułu. Postawiła tam następujące pytania: „Czy starzejąca się wdowa to jeszcze kobieta? Czy może tracąca atrybuty młodości i osamotniona $\mathrm{w}$ wyniku śmierci męża, staje się obiektem, który nie ma prawa do oceny własnego ciała - zachwytu nad własnym ciałem? Jak obiektywnie istniejące straty kształtują indywidualne doświadczanie siebie przez kobiety wdowy?" (s. 264). Zarówno tytuł tekstu, jak i wskazany fragment w sposób nieuprawniony zapowiadają zawartość artykułu, w którym doświadczanie kobiecości ostatecznie nie jest empirycznie analizowane. Interpretowanie zaś wyników dotyczących poczucia zadowolenia / niezadowolenia z poszczególnych części ciała i jego funkcji w kategoriach doświadczania kobiecości lub jej utraty (co w naszej opinii sugerują określenia ,już nie kobieta” czy „czy to jeszcze kobieta") wydaje się nam nadmiarowe i nietrafne. Prowadzona w tym duchu narracja przyczynia się, wbrew deklaracjom badaczki, do potwierdzenia stereotypowego negatywnego obrazu badanej grupy.

Innym przykładem odnoszącym się do problemu popularyzacji wiedzy jest praca pt. Macierzyństwo jako płaszczyzna permanentnego rozwoju kobiety w biegu życia, opublikowana na łamach „Psychologii Rozwojowej” (Mądry 2013). Artykuł stanowi propozycję opisu przebiegu przygotowania i realizacji roli macierzyńskiej kobiet przez analogię do pór roku, ze wskazaniem na fazowość i jakościową odmienność poszczególnych etapów pełnienia roli matki. W uzasadnieniu 
tej metafory autorka pisze: „Świadome doświadczanie przez kobiety regularnie powtarzających się procesów fizjologicznych ułatwia im myślenie o własnym życiu w kategorii etapów (m.in. wzorowanych na porach roku), pomimo rozpowszechnionej $\mathrm{w}$ społeczeństwie linearnej koncepcji czasu i nastawienia na modus "tu i teraz» oraz obserwowalnego zdystansowania człowieka wobec przyrody i jej praw" (s. 11-12). Dalsza narracja artykułu zawiera argumentację na rzecz bliskości i analogii doświadczeń kobiety oraz świata przyrody i jego cykliczności. Można zapytać, skąd przekonanie autorki o uniwersalnym sposobie takiego doświadczania u kobiet, a także o jego odmienności od „doświadczania rozpowszechnionego w społeczeństwie”, którego kobiety są przecież częścią.

Inną ważną cechą tej narracji jest wyznaczanie i opisywanie kolejnych faz rozwoju realizacji macierzyńskiej przez odnoszenie ich wyłącznie do faz rozwoju dziecka (np. narodziny, dojrzewanie, usamodzielnianie się) i rodziny (autorka korzysta z koncepcji fazowego rozwoju rodziny i takich określeń jak „matka z małym dzieckiem”, „matka z syndromem pustego gniazda”). Pisze na przykład: „Okres dorastania kobiety w roli matki kończy osiągnięcie przez dziecko dorosłości i rozpoczęcie przez nie nowego okresu rozwojowego" (s. 14). Wydaje się, że znaczącym brakiem proponowanej konceptualizacji jest pomijanie wpływu indywidualnych właściwości i własnej aktywności na zmiany realizacji roli macierzyńskiej. Zmiany te wynikać mogą na przykład ze zmian fizycznych, które kobiety te przechodzą w cyklu swojego życia, zmian ich relacji partnerskich, zaangażowania zawodowego. Ponadto konieczne wydaje się także branie pod uwagę indywidualnych różnic w sposobie pełnienia roli macierzyńskiej.

Brakuje nam również $\mathrm{w}$ narracji autorki uwzględnienia znaczenia szerszego kontekstu społecznego, w którym kobiety realizują rolę macierzyńską. We wstępie czytamy: „We współczesnych rodzinach przepisy roli matki stają się coraz bliższe zadaniom ojcowskim, choć ciągle jeszcze daje się wyodrębnić cechy i zachowania charakterystyczne wyłącznie dla matek. Tym, co cechuje rolę rodzicielską kobiet, jest przede wszystkim bliski kontakt emocjonalny z dzieckiem oraz zaspokajanie jego potrzeb psychicznych. [...] Niezmiernie ważną funkcją przypisaną matce jest także troska o byt fizyczny dziecka, wyrażająca się w działaniach opiekuńczych. Niezmiennie od pokoleń matka jest też odpowiedzialna za wprowadzanie dziecka do szeroko rozumianej sfery spraw codziennych oraz relacji społecznych i świata transcendencji" (s. 11). Przedstawienie kontekstu pełnienia roli macierzyńskiej wydaje się tu niewystarczające - pomija ogromne zróżnicowanie i przemiany zachodzące $\mathrm{w}$ tym zakresie $\mathrm{w}$ obrębie rodzin, a także w szerszych kontekstach społecznych, na przykład zmiany prawne oddziałujące na sytuacje poszczególnych rodzin, zwiększenie skali migracji i odłączenia od codziennego wsparcia rodzin pochodzenia. W efekcie takiej narracji powstaje wrażenie macierzyństwa jako podstawowego obszaru rozwoju kobiet, który odbywa się w jednakowy dla wszystkich kobiet sposób, jest reaktywny, warunkowany przemianami rozwojowymi dzieci i rodziny jako całości. 


\section{PODSUMOWANIE}

Celem naszym było zaproszenie do podjęcia rozważań na temat zależności między wiedzą potoczną a budowaniem wiedzy naukowej dotyczącej obszaru płci. Nie odnosząc się do istoty pojęcia płci oparłyśmy się na założeniach myśli konstrukcjonistycznej twierdząc, że płeć rozumiana jako kategoria kulturowo-społeczna jest wytwarzana między innymi w tekstach naukowych, także psychologicznych. Potoczne sposoby myślenia o płci i budowanie wiedzy naukowej na jej temat są wzajemnie powiązane. Płeć traktujemy przy tym jako pojęcie o szczególnym znaczeniu: jest to jedna $z$ kategorii podstawowych dla jednostek i grup społecznych, pełni ważne funkcje regulacyjne, a jej społeczno-kulturowe definicje znajdują odzwierciedlenie w obyczajach i praktykach społecznych. Z tych właśnie powodów twierdzimy, że sposób posługiwania się kategorią płci powinien być poddawany wnikliwemu oglądowi, zwłaszcza przez naukowców $\mathrm{w}$ toku ich własnej pracy. Jest to ważne zwłaszcza w tych społeczeństwach, w których wiedza naukowa jest wysoce wartościowana, takich jak społeczeństwo polskie.

Dokonany przez nas krytyczny przegląd wybranych tekstów psychologicznych wskazuje na istnienie różnego rodzaju uchybień (mniej i bardziej subtelnych), które w przebiegu procesu badawczego reprodukują stereotypowy, potoczny obraz pojęcia płci. Pragniemy podkreślić, że lektura polskich czasopism psychologicznych dostarcza także wielu przykładów dobrych praktyk, których $z$ uwagi na charakter naszego opracowania nie zaprezentowałyśmy. Jakkolwiek część przedstawionych niedociągnięć jawi się jako efekt automatycznego przetwarzania informacji na temat płci, to brak refleksji nad tym zagadnieniem jest - w naszym mniemaniu - wysoce niekorzystnym zaniechaniem. Przeprowadzone analizy obejmowały wyłącznie teksty recenzowane, co wskazuje na możliwość występowania podobnych automatyzmów także w pracy recenzenckiej. Wydaje nam się to niepokojące w świetle licznych doniesień na temat niekorzystnych skutków oddziaływania stereotypów płciowych na wieloaspektowy dobrostan człowieka (Brannon 2002; Deaux, Kite 2002; Mandal 2000), jak również $\mathrm{w}$ świetle wartości podzielanych przez polskie i europejskie społeczeństwo, takich jak prawo człowieka do samostanowienia czy równość płci.

Do wskazanych wartości odwołują się opracowane przez polskie środowisko akademickie dokumenty opisujące standardy pracy także w zakresie oddziaływania nauki na życie społeczne. Mowa jest w nich między innymi o wykorzystywaniu wiedzy, intelektu i autorytetu „w praktycznej działalności dla dobra społecznego i międzynarodowego" (punkt 8.1 dokumentu Dobre obyczaje w nauce. Zbiór zasad i wytycznych Komitetu Etyki w Nauce PAN z 2001r.). W wytycznych Kodeksu Etyczno-Zawodowego Psychologów (PTP 1991) także znajdują się zapisy istotne dla prowadzonych w tym miejscu rozważań. „Psychologia ze względu na swą bliskość z życiem społecznym jest tą dziedziną nauki, której wyniki mogą być nadużywane w celu kształtowania przekonań i zachowania 
ludzi. Podejmując badania naukowe psycholog starannie rozważa ich stronę etyczną, a zwłaszcza możliwe pozytywne i negatywne konsekwencje udostępnienia wyników badań i ich wykorzystania w praktyce społecznej" (z art. 29 KEZP) czy „Psycholog jako członek społeczności akademickiej realizuje naczelne wartości etyczne swojego zawodu, jak godność, podmiotowość i autonomia człowieka" ( $z$ art. 42 KEZP).

W świetle przytoczonych deklaracji na temat wartości, którym hołduje polskie środowisko psychologiczne, podniesienie tematu reprodukowania na gruncie psychologii stereotypów związanych z płcią postrzegamy jako kwestię wysokiej wagi. Uznając znaczenie, jakie dla wieloaspektowego funkcjonowania człowieka ma płeć w wymiarze cielesnym, doświadczeniu psychicznym i rozpoznaniu społecznym, widzimy tę kategorię jako wymagającą uwzględnienia w podejmowanej przez psychologów działalności, jeżeli ma być ona działalnością trafną i użyteczną. Trafną z perspektywy bieżącego stanu wiedzy, także o obszarach dyskusyjnych. Użyteczną zaś z perspektywy jednostek i grup, na rzecz których owa działalność jest podejmowana, tak by prowadziła do polepszania jakości życia, nie powodując jednocześnie cierpienia, szkody czy wzmacniania społecznych nierówności (por. Greaves 2012).

Istotne wydaje się także postawienie pytania, co powoduje, że mimo dostępu do wiedzy i rozwiązań wypracowanych przez towarzystwa i instytucje $\mathrm{w}$ innych krajach w ciągu ostatnich trzydziestu lat w Polsce wciąż brakuje dokumentów wprost odnoszących się do zagadnienia płci i seksizmu w działalności psychologicznej (naukowej i praktycznej). Tematyka płci jawi się nam jako z jednej strony szczegółowa, z drugiej — szczególna. Ponieważ stanowi kwestię szczegółową w stosunku do sformułowanych ogólnych wytycznych na temat etyki pracy psychologicznej, wydawać by się mogło, że właśnie one regulują go wystarczająco. Jest jednak kwestią szczególną, czego wykazanie było celem tego opracowania. Wytwarzanie wiedzy naukowej w obszarze dotyczącym tak podstawowych kategorii regulujących zachowania człowieka może uruchamiać, naszym zdaniem, zjawisko opisane $\mathrm{w}$ nieco innym kontekście przez Jerzego Brzezińskiego (2004) jako filtr ideologiczny, gdy uznana apriorycznie za słuszną idea stanowi punkt odniesienia dla określania wartości wiedzy naukowej i sensu jej aplikacji w praktyce społecznej. Mając na względzie ryzyko związane $z$ taką sytuacją widzimy potrzebę podjęcia dyskusji nad opisanymi kwestiami w rodzimym środowisku zawodowym.

\section{BIBLIOGRAFIA}

American Psychological Association, 1977, Guidelines for nonsexist language in APA journals. American Psychological Association Publication Manual Task Force, „American Psychologist”, t. 32 (6), s. 487$-494$.

American Psychological Association, 2010, Publication Manual of the American Psychological Association, APA, Washington DC. 
American Philosophical Association, 1986, Guidelines for Non-Sexist Use of Language, „Proceedings and Addresses of the American Philosophical Association”, t. 59 (3), s. 471-482.

Beall Anne E., 2002, Społeczno-konstruktywistyczne podejście do rodzaju, tłum. Sylwia Pikiel, w: Bogdan Wojciszke (red.), Kobiety i mężczyźni: odmienne spojrzenia na różnice, GWP, Gdańsk.

Bancroft John, 2013, Seksualność człowieka, tłum. Rafał Śmietana, Elsevier Urban \& Partner, Wrocław.

Bilikiewicz Tadeusz, 1939, Uwagi nad artykułem Ludwika Flecka, „Przegląd Współczesny”, nr 8-9, s. $175-167$.

Brannon Linda, 2002, Psychologia rodzaju, tłum. Magdalena Kacmajor, GWP, Gdańsk.

Brzeziński Jerzy, 2004, Metodologia badań psychologicznych, Wydawnictwo Naukowe PWN, Warszawa.

Brzeziński Jerzy M., Toeplitz-Winiewska Małgorzata (red.), 2000, Etyczne dylematy psychologii, Wydawnictwo Fundacji Humaniora, Poznań.

Butler Judith, 2008, Uwikłani w płeć, tłum. Karolina Krasuska, Wydawnictwo Krytyki Politycznej, Warszawa.

Chlewiński Zbigniew, 1995, Tożsamość a tolerancja, „Czasopismo Psychologiczne”, t. 1 (3), s. 119 -128 .

Chrisler Joan C., McCreary Donald R. (red.), 2010, Handbook of gender research in psycholog, Springer, New York.

Cross Susan E., Marcus, Hazel R., 2002, Płeć w myśleniu, przekonaniach i działaniu: podejście poznawcze, tłum. Sylwia Pikiel, w: Bogdan Wojciszke (red.), Kobiety i mężczyźni: odmienne spojrzenia na różnice, GWP, Gdańsk.

Czarnacka Agata, 2014, Konstruktywizm społeczny, w: Monika Rudaś-Grodzka, Katarzyna Nadana-Sokołowska, Agnieszka Mrozik, Kazimiera Szczuka, Katarzyna Czeczot, Barbara Smoleń, Anna Nasiłowska, Ewa Serafin, Agnieszka Wróbel (red.), Encyklopedia Gender. Płeć w kulturze, Instytut Badań Literackich PAN-Wydawnictwo Czarna Owca, Warszawa.

Czerw Agnieszka, Borkowska Anna, 2010, Praca zawodowa jako obszar misji spotecznej, „Psychologia Społeczna", t. 5 (4), s. 303-315.

Czyżowska Dorota, Oleszkowicz Anna, 2010, Związek między rozwojem myślenia moralnego a tendencja do zachowań agresywnych $w$ sytuacjach trudnych $w$ okresie dorastania, „Psychologia rozwojowa”, t. 15 (2), s. 47-59.

Deaux Kay, Kite Mary, 2002, Stereotypy płci, tłum. Sylwia Pikiel, w: Bogdan Wojciszke (red.), Kobiety i mężczyźni: odmienne spojrzenia na różnice, GWP, Gdańsk.

Denmark Florence., Russo Nancy F., Frieze Irene H., Sechzer Jeri A., 1988, Guidelines for Avoiding Sexism in Psychological Research, „American Psychologist”, t. 43 (7), s. 582-585.

Fausto-Sterling Anne, 1993, The Five Sexes. Why Male and Female Are Not Enough?, „The Sciences”, March/April, s. 19-25.

Fausto-Steling Anne, 2000, Sexing the Body, Basic Books, New York.

Ferguson George A., Takane Yoshio, 1997, Analiza statystyczna w psychologii i pedagogice, tłum. Michał Zagrodzki, Wydawnictwo Naukowe PWN, Warszawa.

Fleck Ludwik, 1986, Powstanie i rozwój faktu naukowego. Wprowadzenie do nauki o stylu myślowym i kolektywie myślowym, tłum. Maria Tuszkiewicz, Wydawnictwo Lubelskie, Lublin.

Fleck Ludwik, 2006, Psychosocjologia poznania naukowego, tłum. Maria Tuszkiewicz, Wydawnictwo Uniwersytetu Marii Curie-Skłodowskiej, Lublin.

Gergen Kenneth, 1985, The Social Constructionist Movement in Modern Psychology, „American Psychologist", t. 40 (3), s. 266-275.

Gergen Mary M., Davis Sara N., 1997, Toward a New Psychology of Gender, Routledge, New York. 
Greaves Lorraine, 2012, Why Put Gender and Sex Into Health Research? w: John L. Oliffe, Lorraine Greaves (red.), Designing and conducting gender, sex, and health research, Sage Publications, Los Angeles.

Greenwald Anthony G., Banaji Mahzarin R., 1995, Implicit social cognition: Attitudes, self-esteem, and stereotypes, „Psychological Review”, t. 102, s. 4-27.

Grzelak Szymon, 2006, Profilaktyka ryzykownych zachowań seksualnych mtodzieży, Scholar, Warszawa.

Hare-Mustin Rachel T., Marecek Jeanne, 1988, The Meaning of Difference: Gender Theory, Postmodernism, and Psychology, „American Psychologist”, t. 43 (6), s. 455-464.

Hardin Courtis D., Banaji Mahzarin R., 2010, The Nature of Implicit Prejudice: Implications for Personal and Public Policy, w: Eldar Sharif (red.), The Behavioral Foundations of Public Policy, Princeton University Press, Princeton, New Jersey.

Howard George, 1985, The Role of Values in the Science of Psychology, „American Psychologist”, t. 40 (3), s. 255-265.

Johnson Joy L., Greaves Lorrine, Repta Robin (2007), Better Science with Sex and Gender: A Primer for Health Research, Women's Health Research Network, Vancouver.

Kamiński Stanisław, 1992, Nauka i metoda. Pojęcie nauki i klasyfikacja nauk, KUL, Lublin.

Kaźmierczak Maria, Kiełbratowska Bogumiła, Lewandowska-Walter Aleksandra, Michałek Justyna, Błażek Magdalena, 2012, Charakter więzi rodzinnych oraz uwarunkowania ich kształtowania się w sytuacji okołoporodowej, „Psychologia Rozwojowa”, t. 17 (2), s. 23-39.

Kleka Paweł, 2011, Statystyczne kryteria przydatności raportu z badań do metaanalizy, w: Jerzy M. Brzeziński (red.), Metodologia badań społecznych. Wybór tekstów, Zysk i S-ka Wydawnictwo, Poznań.

Kofta Mirosław, 2005, Kilka uwag o naturze i ewolucji nurtu poznania społecznego, w: Małgorzata Kossowska, Magdalena Śmieja, Sławomir Śpiewak (red.), Społeczne ścieżki poznania, GWP, Gdańsk.

Komitet Etyki w Nauce Polskiej Akademii Nauk, 2001, Dobre obyczaje w nauce. Zbiór zasad i wytycznych (http://www.paleo.pan.pl/documents/Kodeks_Etyczny_PAN.pdf [10.07.2015]).

Kościańska Agnieszka, 2014, Płeć, przyjemność i przemoc, Wydawnictwo Uniwersytetu Warszawskiego, Warszawa.

Krasuska Karolina, 2014, Gender (płeć), w: Monika Rudaś-Grodzka, Katarzyna Nadana-Sokołowska, Agnieszka Mrozik, Kazimiera Szczuka, Katarzyna Czeczot, Barbara Smoleń, Anna Nasiłowska, Ewa Serafin, Agnieszka Wróbel (red.), Encyklopedia Gender. Płeć w kulturze, Instytut Badań Literackich PAN-Wydawnictwo Czarna Owca, Warszawa.

Kuczyńska Alicja, 1992, Inwentarz do oceny ptci psychologicznej, Wydawnictwo PTP, Warszawa.

Laqueur Thomas W., 1990, Making Sex: Body and Gender form Greeks to Freud, Harvard University Press, Cambridge.

Macintyre Sally, 1982, „Kto chce dzieci?” Społeczne fabrykowanie instynktów, tłum. Teresa Hołówka, w: Teresa Hołówka (red.), Nikt nie rodzi się kobieta, Czytelnik, Warszawa.

Malina Alicja, Suwalska Dorota, 2012, Przywiazanie $i$ satysfakcja z realizacji zadań rozwojowych $w$ bliskich zwiazkach a zachowania agresywne między partnerami, „Psychologia Rozwojowa”, t. 17 (2), s. 71-86.

Mandal Eugenia, 2000, Podmiotowe i interpersonalne konsekwencje stereotypów zwiazanych z ptcia, Wydawnictwo Uniwersytetu Śląskiego, Katowice.

Maruszewski Tomasz, 2003, Psychologia poznania, GWP, Gdańsk.

Mądry Maria, 2013, Macierzyństwo jako płaszczyzna permanentnego rozwoju kobiety w biegu życia, „Psychologia Rozwojowa", t. 17 (3), s. 9-21.

Morawski Jill, 1985, The measurement of masculinity and femininity: Engendering categorical realities, „Journal of Personality, t. 53 (2), s. 196-223.

Napora Elżbieta, 2003, Tożsamość ptciowa chłopców wychowywanych przez samotne matki, „Małżeństwo i Rodzina", nr 4 (5), s. 34-38. 
Niewiedział Dorota, 2014, Już nie kobieta? Samoocena atrakcyjności ciała starzejących się wdów, „Dyskursy Młodych Andragogów", t. 15, s. 263-278.

Pankalla Andrzej, 2013, Kultura psychologów, Poznańskie Wydawnictwo Psycho-Kulturowe, Poznań. Piber-Dąbrowska Kinga, 2008, Stereotyp a logiczne wnioskowanie, „Psychologia Społeczna”, t. 32 (7), s. 124-132.

Polskie Towarzystwo Psychologiczne, 1991, Kodeks Etyczno-Zawodowy Psychologa (http://ptp.org.pl/ modules.php? name $=$ News \&file $=$ article \&sid $=29[15.07 .2015])$.

Siudem Anna, 2013, Zachowania ryzykowne młodzieży gimnazjalnej, „Psychologia Rozwojowa”, t. 18 (1), s. 69-85.

Strelau Jan (red.), 2000, Psychologia. Podręcznik akademicki, Gdańskie Wydawnictwo Psychologiczne, Gdańsk.

Walsh Mary R., 2003, Wprowadzenie, tłum. Paweł Cichawa, w: Mary R. Walsh (red.), Kobiety, mężczyźni i płeć. Debata w toku, Wydawnictwo IFiS PAN, Warszawa.

Wendland Michał, 2011, Konstruktywizm komunikacyjny, Wydawnictwo Naukowe IF UAM, Poznań. West Candace, Fenstermaker Sarah, 2003, Wytwarzanie różnicy, tłum. Paweł Cichawa, w: Mary R. Walsh (red.), Kobiety, mężczyźni i płeć. Debata w toku, Wydawnictwo IFiS PAN, Warszawa.

Zwierżdżyński Marcin, 2012, Konstruktywizm a konstrukcjonizm, „Principia”, t. 56, s. 117-135.

Zentrale Gleichstellungsbeauftragte der Universität Potsdam, 2012, Leitfaden zur Anwendung einer gendergerechten Sprache (http://www.uni-potsdam.de/fileadmin/projects/gleichstellung/assets/OEffentlichkeitsarbeit/Publikationen/Leitfaden_2013.pdf [15.07.2015]).

\section{CONSTRUCTION OF STEREOTYPICAL IMAGES OF MEN AND WOMEN IN SELECTED POLISH SCHOLARLY PUBLICATIONS IN THE FIELD OF PSYCHOLOGY}

\section{Sum mary}

The authors analyze selected contemporary Polish academic publications on psychology in order to demonstrate how the concept of gender is constructed in them. They refer to the premises of Kenneth Gergen's social constructionism, and Ludwik Fleck's description of connections in common knowledge. In presenting the bases of constructionist ideas, they concentrate on the process of creating knowledge in the social sciences, its interaction with common knowledge, and the significance of gender categories. They also describe the activities that have been undertaken since the 1980s-on the basis of western psychology-to eliminate negative gender stereotypes from scientific and scholarly works. The nature of the errors and shortcomings that could appear at successive stages of the research process forms a departure point for analyzing examples of stereotypical images of men and women in peer-reviewed empirical works published in Poland after 2000. The summary refers to the Polish regulations in regard to the professional ethics of psychologists and in respect to conducting scientific research.

\section{Key words / słowa kluczowe}

social constructionism / konstrukcjonizm społeczny, gender stereotypes / stereotypy płci, knowledge production / wytwarzanie wiedzy, scientific literature on psychology / psychologiczna literatura naukowa 